\title{
E-Banking Functionality as a Measure of Customer Satisfaction
}

\section{Kombo Felix}

Paulík Jiří

\section{Kwarteng Michael}

Tomas Bata University in Zlin, Faculty of Management and Economics, Department of Enterprise Economics Mostni 5139, 76001 Zlin, Czech Republic; Email: kombo@fame.utb.cz; jiri.paulik@email.cz;adukwart@gmail.com

\section{Doi:10.5901/mjss.2015.v6n6p133}

\begin{abstract}
Globally, 1 in 4 people use electronic banking (e-banking) functionality. This indicates how the service has become the commonly used channel in the banking sector and has therefore, replaced the traditional channel for most banking services. People have embraced this functionality and its usage has become more popular in measuring customer satisfaction. Banks have also benefitted from e-banking through creation of memorable customer experiences for their clients thus retaining them. The aim of this paper is to investigate the satisfaction of Czech and Kenyan bank customers with emphasis on the usage of ebanking. The results from the questionnaires were administered to 323 respondents from the Czech Republic and 403 respondents from Kenya. SPSS 22.0 has been used to analyze the results. The overall levels of satisfaction are different. Majority of users of e-banking have university education. Both satisfaction and dissatisfaction by e-banking is determined by some demographic factors.
\end{abstract}

Keywords: E-banking, customer satisfaction, bank customers, Czech Republic, Kenya

\section{Introduction}

Electronic quality is the most important predictor of customer satisfaction and loyalty (Petnji-Yaya et al., 2013). They further state that antecedents such as online service quality and satisfaction can be used to forecast customer loyalty in e-banking. As a result, many financial institutions have now adapted technological advancements to enhance clients' positive experiences with their services, thereby, ensuring maximum customer satisfaction that lead to customer retention. According to a survey by Ernst \& Young (2014), customers are satisfied with the convenience of traditional banking but expectations are constantly rising as new technologies and consumer behaviors develop. To stay competitive, financial institutions need to continuously develop channel capabilities to provide $24 / 7$ real-time access. Besides, Grigouridis et al. (2013) argue that commercial banks have been forced to operate with emphasis on customer services due to strong competition and long-term achievement since it is linked to bank's ability to adapt to changes of customers' preferences and needs. E-banking is an example of such technological advancement.

According to Liébana-Cabanillas et al (2013), bank branches (traditional channel) have lost significant terrain to ebanking and telephone banking and the level of satisfaction with online banking is increasing. They also state that ebanking has become an essential service to secure client loyalty by ensuring greater customer satisfaction and building stronger ties with clients. They further state that the integration of e-banking into the multi-channel strategy of financial institutions provides higher quality service and achieves greater satisfaction among clients. Apart from customer loyalty, customer satisfaction also leads to customer complaint (Shi and Zhao, 2007). Customer complaints should be solved through various service delivery strategies (Ramachandran and Chidambaram, 2012). They argue that this is done because customer satisfaction not only means satisfying the customers, but also customer retention in case of service failure.

Many commercial banks use e-banking as a mechanism for differentiation from competitors while most customers are using this functionality to choose for banks to be clients to (Liébana-Cabanillas et al., 2013).

Tsiakis et al (2013) also argue that banks are embracing e-banking as a service to reach a wider market share, increase customer satisfaction and lower operational costs. Nami (2009) defines e-banking as the provision of retail and small value banking products and services through electronic channels. These channels include automated teller machines (ATMs), telephone banking, mobile phone banking, internet banking (online), PC banking (offline) and TV- 
based banking.

Table 1 shows the features of e-banking.

Table 1. Features of e-banking. Source: Nami (2009)

\begin{tabular}{|c|c|}
\hline E-banking features for customers & $\begin{array}{c}\text { E-banking features for } \\
\text { banks }\end{array}$ \\
\hline Time saving & More efficient \\
\hline Cost saving & Reducing costs \\
\hline Fast & Borderless (Scalable) \\
\hline Accessible & Dependence on $\mathrm{T}$ \\
\hline Available & Various services \\
\hline
\end{tabular}

Zondiros et al (2007) define customer satisfaction as a measure of how a firm's product or service performs compared to customer's expectations. According to Hoq and Amin (2010), customer satisfaction is the most important driver in commercial banks since higher customer satisfaction leads to lower intention for customers to switch banks.

The main goal of the article was to examine the use of e-banking as a measure of customer satisfaction. The countries for investigation were Czech Republic and Kenya. As part of the research objective, the overall satisfaction of bank customers based on gender, age and education structure has been analyzed and satisfaction and dissatisfaction with e-banking have been examined. The rest of the article is structured as follows: Part 2 explains the drivers of customer satisfaction in commercial banks and discusses the impact of e-banking to clients and banks. Part 3 discusses the sampling frame, method of data collection, analysis used and development of hypotheses and scientific assumption. Part 4 gives the results of our research. Part 5 discusses the results and compare with other past researches. Part 6 concludes this article.

\section{Literature Review}

\subsection{Drivers of Customer Satisfaction in Commercial Banks}

Satisfaction reflects the psychological case or emotional feeling that may affect the consumer as a result of comparison between performance, good service and expectations (Khartabiel and Saydam, 2014). Munari et al (2013) state that customer satisfaction is the primary criterion for the assessment of banks' relationships with the market. Furthermore, Belás and Homolka (2013) state that customer satisfaction in banks present an important area of building long-term relationships with clients. Therefore, satisfied bank customers lead to high banks' profits and market shares. De Matos et al. (2009) point out that satisfied customers tend to be more loyal and recommend the bank to other customers. Thus, customer satisfaction is an important antecedent of customer loyalty. In finding competitive advantage, banks might also use customer satisfaction as a key indicator of their long-term strategies.

Arbore and Busacca (2009) state that quality of relationships as a key factor contributor of customer satisfaction. They argue that quality of relationships include responsiveness, competences, assurance, trust, friendliness, courtesy, availability, commitment, flexibility, and communication. However, a research by Singh and Kaur (2011), shows that customer satisfaction in banks is influenced by seven factors namely: employee responsiveness, appearance of tangibles, social responsibility, service innovation, positive word-of-mouth, competence and reliability. Recent developments show that social responsibility has become relevant given the rising importance of global sustainable development and that is why bank customers are likely to observe banks' socially responsible behavior. Lee et al. (2012) argue that Corporate Social Responsibility (CSR) is associated with the trust which influences customer satisfaction and loyalty (retention). Therefore, customers usually derive higher level of satisfaction from products or services that come from companies that are socially responsible.

Employee responsiveness reflects relationship between employee and customer satisfaction known as satisfaction mirror effect. Khartabiel and Saydam (2014) point out that employee satisfaction significantly reflects their behavior towards customers and strengthens the hypothesis that a satisfied employee is a productive employee. Furthermore, it was found out that when a bank acts to improve job satisfaction, it leads to raising customer satisfaction and loyalty. Motivation of employees can make significant difference in service quality and customer satisfaction because most 
services are provided by people (Mandhachitara and Poolthong, 2011). In addition, satisfaction of bank customers is strongly focused on service quality and service innovation.

E-banking as a self-service activity is a factor of satisfaction which is not derived from people. It significantly supports satisfaction with service quality and service innovation. Zhu and Chen (2012) mention that, in an online context, where human interactions are replaced by graphic user interfaces, the important role in customer satisfaction is fairness. Trust is identified as the key mediator of fairness to customer satisfaction (Zhu and Chen, 2012).

\subsection{Benefits of E-banking}

The evolution of e-banking has altered the nature of personal-customer banking relationships and this has brought many advantages to banks that previously relied on traditional banking channels (Gan et al., 2006). A study conducted by Santouridis and Kyritsi (2014), revealed that there are vital influences associated with the use of internet in the banking industry. They further found out that the use of internet creates some suppleness for customers in general and hence they can assess their balance and do transactions electronically at their own convenience. This has furthermore eradicated the traditional way of walking to banking hall for further transactions and seeking of assistance or clarifications if needed.

Nami (2009) mentions better branding and better responsiveness to the market as a benefit of internet banking to banks. This is because banks that offer this service are perceived as leaders in technology implementation and so they enjoy better branding image. Gan et al (2006) also mention increased customer base, cost savings, mass customization, product innovation, marketing, communications, development of non-core businesses and the ability to offer services regardless of geographical location and time as the other benefits of e-banking to commercial banks.

The main benefit of e-banking to customers is the ability to save time (Nami 2009). Table 2 below shows other benefits of e-banking to customers.

Table 2. Benefits of e-banking to corporate customers. Source: Nami (2009)

\begin{tabular}{|ll|}
\hline 1. & Quick and very fast \\
\hline 2. & Continuous access to information \\
\hline 3. & Increased comfort \\
\hline 4. & Reduced cost \\
\hline 5. & Better cash management \\
\hline
\end{tabular}

Conversely, the influx of e-banking with its efficiency, mode of operation and the benefits attached to it is to enhance customer satisfaction and loyalty (Ariff et al., 2013).

\section{Objectives, Materials and Methods}

To achieve the objectives of this research, data has been gathered through the use of questionnaires. Munari et al (2013) point out that customer satisfaction surveys are the main source of information to set strategies aimed at meeting needs or understanding of customer perceptions, most importantly showing relationships and possible areas of improvement for customers. The questionnaires were conducted in 2012 in Czech Republic and in 2014 in Kenya. In the Czech Republic, the questionnaires were administered to bank customers of Česká spořitelna a.s., Komerční banka, GE Money Bank and UniCredit Bank. In Kenya, clients of banks such as Co-operative Bank, K-Rep Bank, Kenya Commercial Bank and Equity Bank were approached.

The valid respondents from the Czech Republic and Kenya were 323 and 403 respectively. Based on the analysis with regard to gender, age and educational level, the respondents in Czech Republic were as follows: 37\% men and 63\% women; $32 \%$ under 30 years, $50 \%$ between $30-50$ years and $18 \%$ above 50 years; and $1 \%$ with primary education, $62 \%$ secondary education and $37 \%$ university education. The respondents in Kenya were as follows: $43 \%$ men and $57 \%$ women; $81 \%$ under 30 years, $18 \%$ between $30-50$ years and $1 \%$ above 50 years; and $1 \%$ with primary education, $10 \%$ secondary education and $89 \%$ university education.

To further achieve the objective of this research, the following hypotheses and scientific assumption have been formulated.

SA1: The overall levels of customers' satisfaction for Czech and Kenyan bank customers are different. However, both are supported by more than $50 \%$ of the respondents. 
H1: E-banking is mostly used by people with university education.

$\mathrm{H} 2$ : Satisfaction and dissatisfaction of e-banking is significantly determined by gender, age and educational level. The hypotheses will be tested using Pearson's chi-square test as shown below. The significance level is 5\%.

$\sum_{i=1}^{r} \sum_{j=1}^{S} \frac{\left(n i j-n^{\circ} i j\right)^{2}}{n^{\circ} i j}$

\section{Results}

The results for the overall levels of customer satisfaction for Czech Republic and Kenya are shown in tables 3 and 4 respectively.

Table 3. The overall level of customer satisfaction in Czech Republic.

\begin{tabular}{|c|c|c|c|c|c|c|c|c|}
\hline \multirow[b]{2}{*}{ Are you satisfied with banking products and services provided? } & \multirow[b]{2}{*}{ 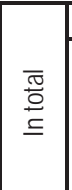 } & \multicolumn{2}{|c|}{ Gender } & \multicolumn{3}{|c|}{ Age } & \multicolumn{2}{|c|}{ Education level } \\
\hline & & $\sum^{\bar{D}}$ & $\begin{array}{l}\bar{\Phi} \\
\text { है } \\
\text { ¿े }\end{array}$ & 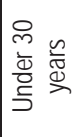 & 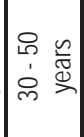 & 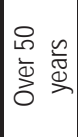 & 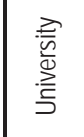 & 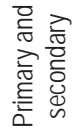 \\
\hline Yes in \% & 62,23 & 55,37 & 66,34 & 64,71 & 59,51 & 65,52 & 66,12 & 59,90 \\
\hline No in $\%$ & 26,32 & 31,40 & 23,27 & 24,51 & 28,83 & 22,41 & 27,27 & 25,74 \\
\hline Don't know in \% & 11,46 & 13,22 & 10,40 & 10,78 & 11,66 & 12,07 & 6,61 & 14,36 \\
\hline Critical values of $x 2$ & & & 990 & & 9,488 & & $5, \mathrm{c}$ & 90 \\
\hline Calculated values of $x^{2}$ & & & 894 & & 1,315 & & 4,4 & 99 \\
\hline
\end{tabular}

Note: Secondary education has been used to also refer to respondents of primary education due to minimum number of responses.

\section{Source: Own}

Czech bank customers (62\%) are satisfied with their banks, $26 \%$ of them are dissatisfied while $11 \%$ of them do not know. More women than men are satisfied with their banks and this is the same with those who are over 50 years old and those people with university education. Furthermore, the value of the test criteria (X2) show that the overall level of customer satisfaction in Czech Republic does not depend on gender, age and education

Table 4. The overall level of customer satisfaction in Kenya.

\begin{tabular}{|c|c|c|c|c|c|c|c|c|}
\hline \multirow[b]{2}{*}{ Are you satisfied with banking products and services provided? } & \multirow[b]{2}{*}{ 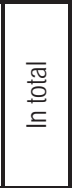 } & \multicolumn{2}{|c|}{ Gender } & \multicolumn{3}{|c|}{ Age } & \multicolumn{2}{|c|}{ Education level } \\
\hline & & $\stackrel{\bar{\Phi}}{\Sigma}$ & $\begin{array}{l}\text { बे } \\
\text { हे } \\
\text { ذे }\end{array}$ & 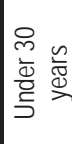 & 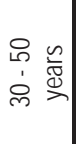 & 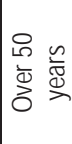 & 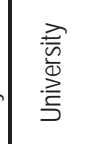 & 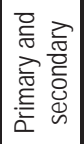 \\
\hline Yes in \% & 63,80 & 58,70 & 67,50 & 64,40 & 63,90 & 20,00 & 63,70 & 64,10 \\
\hline No in $\%$ & 32,80 & 39,00 & 28,10 & 31,90 & 33,30 & 80,00 & 32,70 & 35,90 \\
\hline Don't know in \% & 3,50 & 2,30 & 4,30 & 3,70 & 2,80 & 0,00 & 3,60 & 0,00 \\
\hline \multicolumn{2}{|l|}{ Critical values of $x^{2}$} & \multicolumn{2}{|c|}{5,990} & \multicolumn{3}{|c|}{9,488} & \multicolumn{2}{|c|}{5,990} \\
\hline \multicolumn{2}{|l|}{ Calculated values of $\times 2$} & \multicolumn{2}{|c|}{5,860} & \multicolumn{3}{|c|}{5,325} & \\
\hline
\end{tabular}

Note: Secondary education has been used to also refer to respondents of primary education due to minimum number of responses.

\section{Source: Own source}

Kenyan bank customers (64\%) are satisfied with their banks, 33\% are dissatisfied and 4\% of them do not know. More women (68\%) are satisfied than men (59\%) while people under the age group of under 30 years old (64\%) are more satisfied than other members in the social group of age. People with primary and secondary education are slightly more satisfied than people with university education. Moreover, value of the test criteria (X2) show that the overall level of 
customer satisfaction does not depend on gender, age and education.

Based on the analysis, it has been found out that the overall levels of satisfaction are slightly different between the two countries. Other significant difference can be seen. Kenyan bank customers (33\%) are more dissatisfied than Czech bank customers (26\%). Tables 3 and 4 have confirmed our scientific assumption No. 1.

Tables 5 and 6 depict satisfaction and dissatisfaction respectively of bank customers by e-banking functionality.

Table 5. Satisfaction by e-banking in Czech Republic and Kenya.

\begin{tabular}{|c|c|c|c|c|c|c|c|c|c|}
\hline \multirow{2}{*}{\multicolumn{2}{|c|}{ Satisfaction by e-banking in com }} & \multirow{2}{*}{ 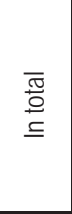 } & \multicolumn{2}{|c|}{$\begin{array}{c}\text { Gender } \\
\times 2=3,84000^{*}\end{array}$} & \multicolumn{3}{|c|}{$\begin{array}{c}\text { Age } \\
\times 2=5,99000^{*}\end{array}$} & \multicolumn{2}{|c|}{$\begin{array}{c}\text { Education level } \\
\times 2=3,84000^{*}\end{array}$} \\
\hline & & & & $\overline{0}$ & 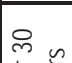 & 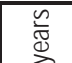 & & 玆 & 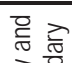 \\
\hline \multirow{2}{*}{ Republic } & $\%$ & 74,61 & 67,77 & 78,71 & 89,22 & 74,23 & 50,00 & 83,47 & 69,30 \\
\hline & $x^{2}$ & & \multicolumn{2}{|c|}{4,785} & \multicolumn{3}{|c|}{30,044} & \multicolumn{2}{|c|}{8,015} \\
\hline \multirow{2}{*}{ E-banking in Kenya } & $\%$ & 45,41 & 48,84 & 42,86 & 43,87 & 55,56 & 0,00 & 46,64 & 35,56 \\
\hline & $x^{2}$ & & \multicolumn{2}{|c|}{1,424} & \multicolumn{3}{|c|}{7,465} & \multicolumn{2}{|r|}{80} \\
\hline
\end{tabular}

Note: * critical values of $x 2$.

\section{Source: Own source}

In Czech Republic, $75 \%$ of the respondents are satisfied with e-banking. Statistically, significant differences are visible. More women (79\%) use e-banking than men (68\%). Respondents under 30 years old (89\%) and people with university education (83\%) are satisfied with this channel. People with university education (83\%) use e-banking more than people with primary and secondary education (69\%). Based on the table 5, we conclude that e-banking is dependent on gender, age and education in Czech Republic.

In Kenya, $45 \%$ of the respondents are satisfied with e-banking. More men (49\%) use e-banking than women (43\%).Statistically, more people in the age group of 30-50 years use e-banking than other members in their social group. More people with university education (47\%) use e-banking services in Kenya. As per the results, we conclude that ebanking in Kenya is not dependent on gender and educational level but rather age.

Based on the above calculations, more people in Czech Republic are satisfied with e-banking than in Kenya. Besides, hypothesis No. 1 has been confirmed.

Table 6. Dissatisfaction by e-banking in Czech Republic and Kenya.

\begin{tabular}{|c|c|c|c|c|c|c|c|c|c|}
\hline \multirow{2}{*}{\multicolumn{2}{|c|}{ Dissatisfaction by e-banking in commercial banks }} & \multirow{2}{*}{$\begin{array}{l}\stackrel{\widetilde{\widetilde{\sigma}}}{0} \\
\text { 品 }\end{array}$} & \multicolumn{2}{|c|}{$\begin{array}{c}\text { Gender } \\
\times 2=3,84000^{*}\end{array}$} & \multicolumn{3}{|c|}{$\begin{array}{c}\text { Age } \\
\times 2=5,99000^{*} \\
\end{array}$} & \multicolumn{2}{|c|}{$\begin{array}{c}\text { Education level } \\
\times 2=3,84000^{*}\end{array}$} \\
\hline & & & & ㄸ & প্লিn & 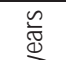 & 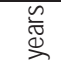 & 謈 & 윯 \\
\hline \multirow{2}{*}{ Poor quality of e-banking in Czech Republic } & $\%$ & 1,86 & 3,31 & 0,99 & 2,94 & 0,00 & 5,17 & 2,48 & 1,49 \\
\hline & $x^{2}$ & & \multicolumn{2}{|c|}{2,226} & \multicolumn{3}{|c|}{7,238} & \multicolumn{2}{|c|}{0,410} \\
\hline \multirow{2}{*}{ Poor quality of e-banking in Kenya } & $\%$ & 34,00 & 31,98 & 35,50 & 32,82 & 37,50 & 60,00 & 32,12 & 48,89 \\
\hline & $x^{2}$ & & \multicolumn{2}{|c|}{0,545} & \multicolumn{3}{|c|}{2,101} & \multicolumn{2}{|c|}{5,008} \\
\hline
\end{tabular}

Note: * critical values of $x 2$.

\section{Source: Own source}

Lower number of Czech bank customers are dissatisfied with e-banking (2\%) than Kenyan bank customers (34\%). Statistically, more people with primary education and secondary education (49\%) are dissatisfied with e-banking than people with university education (32\%) in Kenya.

In Czech Republic, statistically, people over 50 years (5\%) are dissatisfied with e-banking more than other 
members in their social group. According to the results, gender and education are not dependent on e-banking in Czech Republic while age is dependent. In Kenya, gender and age are not dependent on e-banking while educational level is dependent on e-banking.

Tables 5 and 6 have partially confirmed our hypothesis No. 2.

\section{Discussion}

Fonseca (2014) on his research on e-banking culture for 27 EU countries states that e-banking has made it possible for bank customers to conduct transactions anywhere and no longer need to go physically to branches. He further states gender, age and education level as key demographic factors in analyzing usage of e-banking. This research has also made use of these demographic factors.

According to KPMG (2013), 70\% of Kenyans are satisfied with their banks. Based on our research, $64 \%$ of Kenyans are satisfied with their banks. Deloitte (2012) mentions that $50 \%$ or more of Czechs are satisfied with the services of their banks. In comparison to our research, $62 \%$ of people in Czech Republic are satisfied with their banks. As per the research results, the overall levels of customer satisfaction are slightly different between Kenya and Czech Republic.

Ernst \& Young (2014) on their global survey on customer satisfaction and behavior point out that e-banking is the most important reason for customer satisfaction in Czech Republic. They further state that $46 \%$ of Czechs are satisfied with this service. For our research, $75 \%$ of bank customers are satisfied with e-banking. In Kenya, $50 \%$ of the people are satisfied with e-banking contrary to our research whereby $45 \%$ were satisfied with the channel. Gikandi and Bloor (2010) argue that cost reduction and customer related factors are the main drivers of e-banking adoption in Kenya. They also state that the e-banking sector will continue to evolve as banks continue to venture into rapidly changing and emerging technologies to enable them expand their customer horizon through differentiated products, increased customer awareness and choices, and enhanced security.

A research by Meyer et al., (2006) for Deutsche Bank on online banking found out that individuals with higher formal education are more likely to use the internet and do financial transactions online. Furthermore, better educated people are typical early adopters and have fewer reservations against any technology. Fonseca (2014) also states that people with high level of education are the likely users of e-banking. Our research also has the same conclusion since more people with university education use e-banking. Fonseca (2014) also mentions gender, age and education level as the determinants of the usage of e-banking. For our research, these three attributes were partially confirmed.

The findings of this article are important to commercial banks since e-banking is the commonly used channel and therefore, there is need for banks to adapt to such technological advancements to create a lasting relationship with customers. As pointed out, e-banking has a quite number of positive impacts but most importantly leads to customer satisfaction, customer loyalty, reduced operational cuts and increased market share. These impacts are also achieved if there is maximum satisfaction of customers by the service. In addition, based on the findings, managers or decision makers of commercial banks in Czech Republic and Kenya need to come up with other ways of improving use of ebanking to ensure maximum customer satisfaction among different social groups.

\section{Conclusion}

This research has looked at e-banking as a measure of customer satisfaction in commercial banks in Czech Republic and Kenya. Literature on drivers of customer satisfaction and benefits of e-banking in commercial banking has been taken into account. Questionnaires were used as a method of data collection and the results were analyzed according to gender, age and educational level.

Based on the findings, the overall level of satisfaction in Czech Republic is $62 \%$ while $64 \%$ in Kenya. This confirmed our scientific assumption No. 1.

The usage of e-banking is determined by the level of education. People with university education use e-banking more than other members of the social group of education. This is because of their easy adaptability to usage of this channel. This confirmed our hypothesis No. 1.

Satisfaction of bank customers by e-banking in Czech Republic is $75 \%$ while $45 \%$ in Kenya. It was found that satisfaction by e-banking in Czech Republic is dependent on gender, age and education contrary to Kenya, whereby it is only dependent on age. Dissatisfaction of Czechs (2\%) with e-banking is less than for Kenyans (34\%). Age determines dissatisfaction in Czech Republic while educational level determines dissatisfaction in Kenya. These results partially confirmed our hypothesis No. 2. 
As a managerial recommendation for commercial banks in Kenya, there is need for them to advocate for the usage of e-banking services. Therefore, we recommend development of advertising campaigns aimed at each social group in accordance with gender, age and education level. There is also need for informing and educating bank customers in Kenya on the benefits of usage of e-banking.

Future research should focus on the possible reasons behind the usage of e-banking for the different age groups.

\section{Acknowledgement}

The authors are thankful to the Internal Grant Agency of FaME TBU No. IGA/FaME/2015/025: The possibilities of the financial performance growth for commercial banks in the context of the credit risk of SME and the customer satisfaction, for financial support to carry out this research.

\section{References}

Arbore, A., \& Busacca, B. (2009). Customer satisfaction and dissatisfaction in retail banking: Exploring the asymmetric impact of attribute performances. Journal of Retailing and Consumer Services, 16(4), 271-280.

Ariff, M. S. M., Yun, L. O., Zakuan, N., \& Ismail, K. (2013). The Impacts of Service Quality and Customer Satisfaction on Customer Loyalty in Internet Banking. Procedia-Social and Behavioral Sciences, 81, 469-473. Retrieved from http://www.sciencedirect.com/ science/article/pii/S1877042813015292

Belás, J., \& Homolka, L. (2013). The Development of Customers' Satisfaction in the Banking Sector of Slovakia in the Turbulent Economic Environment. Acta Universitatis Agriculturae et Silviculturae Mendelianae Brunensis, 61, 221.

Deloitte. (2012). Průzkum: Více než čtyrĭ pětiny Čechů jsou věrní své bance (Tlačová správa, 14. 6. 2012). Retrieved from http://www.deloitte.com/view/cs_CZ/cz/press/press- releases/9563e3bf3cae7310VgnVCM2000001b56f00aRCRD.html

de Matos, C. A., Rossi, C. A. V., Veiga, R. T., \& Vieira, V. A. (2009). Consumer reaction to service failure and recovery: the moderating role of attitude toward complaining. Journal of Services Marketing, 23(7), 462-475.

Ernst \& Young (2014). Winning through customer experience: EY Global Consumer Banking Survey 2014. Retrieved from http://www.ey.com/GL/en/Industries/Financial-Services/Banking---Capital-Markets/Global-consumer-banking-survey-2014

Fonseca, J. R. (2014). e-banking culture: A comparison of EU 27 countries and Portuguese case in the EU 27 retail banking context. Journal of Retailing and Consumer Services, 21(5), 708-716.

Gan, C., Clemes, M., Limsombunchai, V., \& Weng, A. (2006). A logit analysis of electronic banking in New Zealand. International Journal of Bank Marketing,24(6), 360-383.

Grigoroudis, E., Tsitsiridi, E., \& Zopounidis, C. (2013). Linking customer satisfaction, employee appraisal, and business performance: an evaluation methodology in the banking sector. Annals of Operations Research, 205(1), 5-27.

Hoq, M. Z., \& Amin, M. (2010). The role of customer satisfaction to enhance customer loyalty. African Journal of Business Management, 4(12), 2385-2392.

Khartabiel, I. M., \& Saydam, S. (2014). Banks Employees Satisfaction as a Lead to Customers Satisfaction. International Journal of Business and Social Science, 5(9), 88-96. Retrieved from http:/lijbssnet.com/journals/Vol_5_No_9_1_August_2014/8.pdf

KPMG, (2013). Africa banking industry customer satisfaction survey. Retrieved from http://www.kpmg.com/CO/es/lssuesAndlnsights/ ArticlesPublications/Documents/Africa_Banking_Industry_Customer_Satisfaction_Survey-April2013.pdf

Lee, Y. K., Kim, Y., Lee, K. H., \& Li, D. X. (2012). The impact of CSR on relationship quality and relationship outcomes: A perspective of service employees. International Journal of Hospitality Management, 31(3), 745-756.

Liébana-Cabanillas, F., Muñoz-Leiva, F., \& Rejón-Guardia, F. (2013). The determinants of satisfaction with e-banking. Industrial Management \& Data Systems, 113(5), 750-767. Retrieved from http://www.emeraldinsight.com/doi/pdfplus/10.1108/0263557131 1324188

Mandhachitara, R., \& Poolthong, Y. (2011). A model of customer loyalty and corporate social responsibility. Journal of Services Marketing, 25(2), 122-133.

Meyer, T., Stobbe, A., Haibach, M., \& Walter, N. (2006). What we learn from the differences in Europe. E-Banking Snapshot, 1-5.

Munari, L., Ielasi, F., \& Bajetta, L. (2013). Customer satisfaction management in Italian banks. Qualitative Research in Financial Markets, 5(2), 139-160.

Nami, M. R. (2009). E-Banking: Issues and Challenges. In Software Engineering, Artificial Intelligences, Networking and Parallel/Distributed Computing, 2009. SNPD'09. 10th ACIS International Conference on (pp. 263-266). IEEE. Retrieved from http://ieeexplore.ieee.org/stamp/stamp.jsp?tp=\&arnumber=5286659

Petnji Yaya, L. H., Marimon, F., \& Casadesus, M. (2013). The contest determinant of delight and disappointment: a case study of online banking. Total Quality Management \& Business Excellence, 24(11-12), 1376-1389.

Ramachandran, A., \& Chidambaram, V. (2012). A review of customer satisfaction towards service quality of banking sector. Social and Management Sciences, 20(2), 71-79.

Santouridis, I., \& Kyritsi, M. (2014). Investigating the Determinants of Internet Banking Adoption in Greece. Procedia Economics and Finance, 9, 501-510.

Shi, B., \& Zhao, G. (2007). Introducing ACSI Model to Measure Customer's Satisfaction for Banking Service. Proceedings of the 2007 
International Conference on Management Science and Engineering, August 20-23, Sydney, Australia.

Singh, J., \& Kaur, G. (2011). Customer satisfaction and universal banks: an empirical study. International Journal of Commerce and Management, 21(4), 327-348.

Tsiakis, T., Kargidis, T., \& Chatzipoulidis, A. (2013). IT Security Governance in E-banking.

Zhu, Y. Q., \& Chen, H. G. (2012). Service fairness and customer satisfaction in Internet banking: exploring the mediating effects of trust and customer value. Internet Research, 22(4), 482-498.

Zondiros, D., Konstantopoulos, N., \& Tomaras, P. (2007, December). A simulation model for measuring customer satisfaction through employee satisfaction. In Computation in Modern Science and Engineering: Proceedings of the International Conference on Computational Methods in Science and Engineering 2007 (ICCMSE 2007): Volume 2, Parts A and B (Vol. 963, No. 2, pp. 10861089). AIP Publishing. 